\title{
Gene therapy investigations proliferate
}

Biomedical research in the US remains consumed with events surrounding the death of Jesse Gelsinger, the Arizona teenager who became the first person to die from gene therapy, at the University of Pennsylvania trial. Last month, it was the turn of the Senate Public Health subcommittee, chaired by Senator Bill Frist (R-TN), to hear testimony on what Frist described as "failing public oversight" the technique. This hearing follows similar investigations by the Food and Drug Administration (FDA) and the National Institutes of Health (NIH) (Nature Med. 6, 6; 2000). More inquests are planned by other groups with a stake in the regulation of medical research.

Frist's hearing followed on

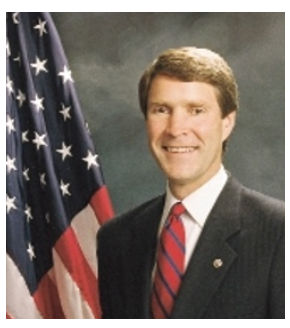

Senator Bill Frist at a RAC hearing last December that the same patient had not responded to the therapy. "That's what hurts the most," he said, "that we were misled."

Gelsinger also faulted federal regulators, claiming an effective RAC reporting system could have alerted his son to serious reactions to adenovirus vectors that were found in other trials. Amy Patterson, director of NIH's Office of Biotechnology Activities, of which RAC is a part, testified that RAC is now at work on such a system which will include a web-interactive database offering rapid access to gene therapy $\mathrm{AE}$ reports. The database may also help regulators spot $\mathrm{AE}$ trends emerging from across disparate gene therapy trials.

Patterson was asked to exthe heels of 22 January suspensions by the FDA of all seven gene therapy trials underway at the university's Human Gene Therapy institute, lead by James Wilson. The suspensions resulted from the FDA's discovery of numerous documentation and reporting violations made during the Gelsinger clinical trial.

Wilson's Institute for Human Gene Therapy has begun to suffer financially. On 28 January, the Muscular Dystrophy Association suspended $\$ 1$ million in grant support to the institute, and the Cystic Fibrosis Foundation suspended enrollments at the institute and Cornell University for trials using the same type of adenovirus vector that killed Gelsinger. The foundation continues, however, to support cystic fibrosis gene therapy using other adenovirus vectors.

Senators focused on two issues: whether Gelsinger had been fully informed of the risk he undertook as a trial participant, and why the NIH's Recombinant DNA Advisory Committee (RAC), which is charged with public oversight of gene therapy, has not been receiving timely reports of gene therapy adverse events (AE).

In a voice quavering with emotion, Paul Gelsinger described his son's death as "an avoidable tragedy from which I will never recover" and accused the institute's researchers of deceiving his son. "In no way was it informed consent," he declared. His son, he said, joined the trial in part because he was told the therapy had benefited another patient. So Paul Gelsinger was surprised to discover plain why a RAC survey of AEs, gathered belatedly after Gelsinger's death, showed that only 6\% (39 of 691) were reported as rapidly as guidelines require. She responded that her office couldn't yet explain why so many reports were late. Contrary to widespread media interpretation, she also had no firm evidence that transfer of the RAC's authority to approve gene therapy protocols to FDA in 1997 was behind the problem. Patterson noted that the RAC might request restoration of its approval authority.

Jay P. Siegel, director of the Office of Therapeutics Research and Review, the FDA office overseeing gene therapy, testified that at least $95 \%$ of the 691 AEs were reported to the FDA on time. Although the FDA has always treated those reports as confidential, whereas the RAC's are public, Siegel said his office is studying whether the law will allow public release of some parts of the FDA reports.

Frist's subcommittee will consider recommendations to address the regulatory problem at a later, unspecified date. In the House, however, there is already legislation that would affect gene therapy trials. Dennis Kucinich (D-OH) last month proposed the creation of a new agency to oversee all federally funded human clinical trials, including gene therapy trials. Kucinich's proposal would transfer oversight authority from the Office for Protection from Research Risks (OPRR), which is part of the Department of Health and Human Services, to a new agency independent of the department and called the Office for Protection of Human Research Subjects.

Frist's inquiry is now one of many. The OPRR plans to investigate the Gelsinger clinical trial; the University of Pennsylvania will have both an internal and external investigation of Wilson's institute; the Commerce Committee of the House of Representatives has decided to hold gene therapy hearings; and Tom Bliley (R-VA), chairman of that committee, has also asked the Inspector General of the Department of Health and Human Services to assess the adequacy of oversight of gene therapy clinical trials. RAC will continue its own examination of $\mathrm{AE}$ reporting issues at a meeting this month. Tom Hollon, Bethesda

\section{Fate of 'Montagnier center' to be decided}

As Nature Medicine went to press, the fate Manhattan. The collapse of the New of Luc Montagnier's proposed AIDS re- York center follows last year's banksearch center in New York City was being determined by three distinguished scientists-none of them an HIV researcher.

It seems most likely that, after failing to become a world-class HIV research institute as promised almost three years ago (Nature Med. 4, 260; 1998), the facilities will be ab-

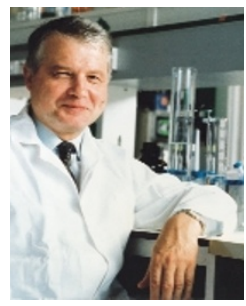

Luc Montagnier ruptcy of Montagnier's Parisbased AIDS laboratory, which went into receivership just three years after it opened (Nature 399, 192; 1999).

Queens College is a unit of City University of New York (CUNY), which set a November 1999 deadline for the college's president, Allen L. Sessoms, to raise the funds necessary to ogy consortium of nine New York research centers planned for the City College of New York campus in uptown continue with the Montagnier project. Sessoms did not meet the deadline, and CUNY Chancellor Matthew Goldstein an- 